\title{
An unusual presentation of a traumatic posterior hip dislocation
}

\author{
Kathryn Rebecca Newton, Murray Thomas du Plessis
}

Department of Accident and Emergency, Nevill Hall Hospital, Abergavenny, Monmouthshire, UK

\section{Correspondence to}

Dr Murray Thomas du Plessis, murrayduplessis@doctors. org.uk

Accepted 5 December 2013
CrossMark

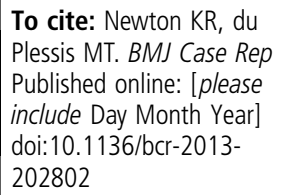

\section{DESCRIPTION}

A 28-year-old man attended the emergency department following an awkward tackle while playing rugby. While in the prone position, another player landed on his lower back. ${ }^{1}{ }^{2} \mathrm{He}$ experienced immediate pain in association with a 'popping' sensation in his left hip. In the emergency department there was no obvious pelvic or lower limb deformity. $\mathrm{He}$ was able to straighten his leg and raise both the legs. He demonstrated only mild tenderness in his left groin and a slight reduction in the left hip flexion and abduction. He was unable to bear weight. For these reasons, pelvis and lateral hip radiographs were requested. These demonstrated a posterior dislocation of the femoral head with an associated acetabular rim fracture (figure 1).

The orthopaedic team performed a reduction of his dislocation under general anaesthesia. The postreduction pelvic radiograph was satisfactory. Further CT imaging of his hip was requested to further evaluate the joint. It demonstrated a comminuted fracture at the posterior-superior acetabular rim (figure 2). A small bone fragment was also demonstrated at the anterior-inferior rim of the acetabulum with the proximal femur appearing intact. Follow-up in an orthopaedic clinic to date has been satisfactory.

This was an unusual case as the mechanism of injury rarely results in such a significant injury. In addition, the patient had few clinical signs which initially led the team to believe he had a much less severe injury.

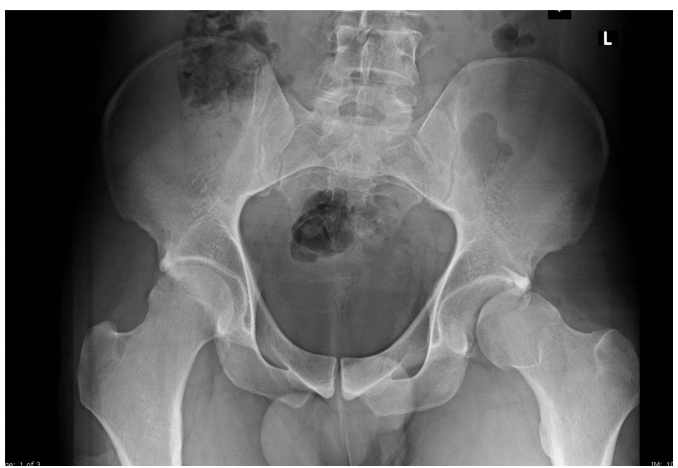

Figure 1 A radiograph of the pelvis demonstrates a posterior dislocation of the femoral head with an associated acetabular rim fracture.

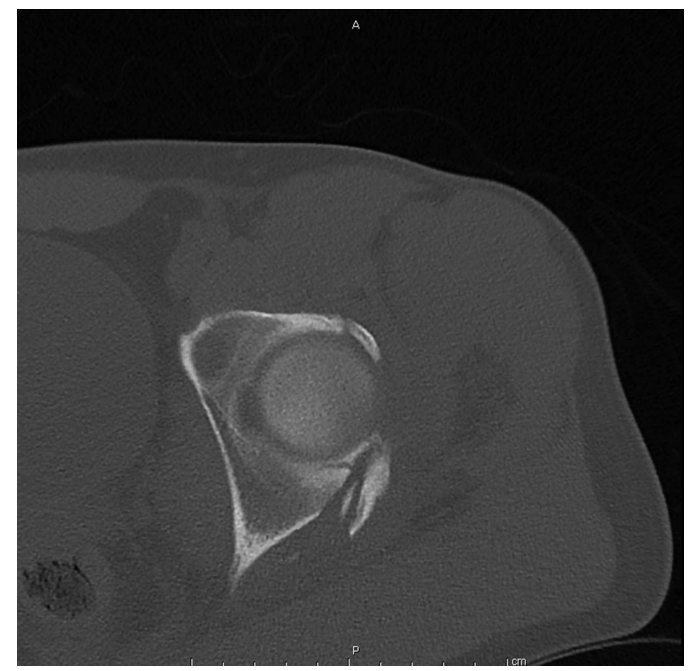

Figure $2 \mathrm{CT}$ of the hip shows a comminuted fracture at the posterior-superior acetabular rim. A small bone fragment is shown at the anterior-inferior rim.

\section{Learning points}

- Posterior hip dislocations are more commonly seen following road traffic collisions and are rarely a result of athletic injuries.

- Usually posterior hip dislocations are extremely painful due to the displaced femoral head resting on the sciatic nerve and present with flexion, internal rotation and adduction of the affected hip.

- Early orthopaedic involvement should be sought with the aim to achieve a timely reduction.

Competing interests None.

Patient consent Obtained.

Provenance and peer review Not commissioned; externally peer reviewed.

\section{REFERENCES}

1 Venkatachalam S, Heidari N, Greer T. Traumatic fracture-dislocation of the hip following rugby tackle: a case report. Sports Med Arthrosc Rehabil Ther Technol 2009;1:28.

2 Yang RS, Tsuang YH, Hang YS, et al. Traumatic dislocation of the hip. Clin Orthop Relat Res 1991;265:218-27. 


\section{Images in...}

Copyright 2014 BMJ Publishing Group. All rights reserved. For permission to reuse any of this content visit http://group.bmj.com/group/rights-licensing/permissions.

BMJ Case Report Fellows may re-use this article for personal use and teaching without any further permission.

Become a Fellow of BMJ Case Reports today and you can:

- Submit as many cases as you like

- Enjoy fast sympathetic peer review and rapid publication of accepted articles

- Access all the published articles

- Re-use any of the published material for personal use and teaching without further permission

For information on Institutional Fellowships contact consortiasales@bmjgroup.com

Visit casereports.bmj.com for more articles like this and to become a Fellow 